\title{
A VOZ NARRATIVA E OS POEMAS NOS DIÁRIOS LITERÁRIOS JAPONESES - TOSA NIKKI E IZUMI SHIKIBU NIKKI
}

Neide Hissae Nagae

RESUMO: Tosa Nikki, o Diário de Tosa, e Izumi Shikibu Nikki, o Diário de Izumi Shikibu, são obras narradas na terceira pessoa do singular e fogem à expectativa criada em tomo de obras como elas que levam o nome de diário. Nesse aspecto, merecem um estudo sobre as implicações que se ocultam sob tal estruturação, suas causas e conseqüências na interpretação das respectivas obras e na formação do Diário Literário japonês no âmbito da Literatura Feminina que floresceu entre os séculos X e XI.

Palavras-chave: Diário Literário, Tosa Nikki, Izumi Shikibu Nikki, Poesia e Prosa, Foco Narrativo.

ABSTRACT: Tosa Nikki, Diary of Tosa, and Izumi Shikibu Nikki, Izumi Shikibu's Diary are narrated in third person, not in first person as we expected in a work like a diary. This structure certainly has the author's intention that needs a study to knows the causes and consequences in the interpretation of these works and in a construction of the japanese diary literature into de Women's literature that florished in X to XI Century in Japan.

Key words: Literary Diary, Tosa Nikki, Izumi Shikibu Nikki, Poetry and Prose, Point of View.

\section{Introdução}

Tosa Nikki, o Diário de Tosa, escrito em 935 pelo renomado poeta da corte Kino Tsurayuki (870-945), e Izumi Shikibu Nikki, o Diário de Izumi Shikibu, datado de 1007, com suposta autoria da dama da corte de quem leva o nome, inserem-se no chamado gênero de Diários Literários que passaram a existir no Japão a partir do final do século $\mathrm{X}$. O autor de Diário de Tosa, a obra que inaugurou esse gênero, foi um dos 36 renomados poetas de sua época. Possui mais de 300 poemas compilados 
em coletâneas editadas por ordem imperial e foi também um dos organizadores da primeira delas, Kokin Wakashū (Coletânea de Poemas Waka de Outrora e de Hoje, 905). O Diário de Izumi Shikibu, o terceiro em termos cronológicos, tem como supostos autores pessoas ligadas à poesia. A primeira delas é Izumi Shikibu (?979-?1036), poetisa de renome que compôs mais de mil poemas reunidos em duas coletâneas, e cujos poemas fazem parte de antologias poéticas editadas por decreto imperial como a já citada Kokin Wakashū e Hyakunin Isshu, (Um poema de Cem Poetas). O segundo suposto autor é Fujiwarano Shunzei (1114-1204), poeta que serviu de juiz a muitos encontros poéticos, a começar pelo Kenshun'mon'in hokumen utaawase, e foi organizador de Senzai Wakashū, (Coletânea de Poemas Waka em Infinidade, 1186) a $7^{\mathrm{a}}$ concluída por ordem imperial.

Pela história da literatura japonesa é possível observar que a chamada Literatura de Diário foi inaugurada pelo poeta da corte Kino Tsurayuki e logo em seguida passou a ser produzido pelas mulheres, sobretudo pelas damas da corte que também atuaram em outras esferas da literatura japonesa criando, nesse período, um universo literário feminino inédito no Japão e no mundo.

Nesse gênero, são poucas as obras de autoria masculina no período clássico e, dentre as que se destacaram, podem ser citadas Meigetsuki (Registro da Lua de Outono, 1235), o diário do poeta Fujiwarano Teika, em que ele registra cerca de 36 anos (1180-1235) sobre as relações dos nobres e militares, os costumes sobre os eventos e etiquetas e expõe opiniões pessoais sobre o poema waka; Kaidokki (Registro (Diário) do Caminho do Leste, \pm 1231 ) e Tökanki (Diário de Viagem pela Costa Leste, $\pm 1235-1242$ ) que parecem ter sido obras de viajantes de Quioto a Kamakura e Chichi no Shüen Nikki (Diário dos Últimos Anos de meu Pai, 1801) do poeta Kobayashi Issa, mas nenhuma delas foi produzida no período áureo dos Diários Femininos.

O desenvolvimento dessa nova forma literária clássica só se tornou possível dentro de um contexto específico: o desabrochar de uma cultura autóctone japonesa, após 894, com o encerramento das dispendiosas expedições culturais japonesas ao continente chinês mantidas desde 607 pela iniciativa de Shōtoku Taishi, Príncipe Regente da Imperatriz Suiko, para desenvolver o Japão por meio da importação intencional da cultura chinesa. Com o distanciamento do Continente, surge uma literatura japonesa propriamente dita desencadeada pela invenção da nova escrita em fonogramas (kana), que gera um aumento e uma diversidade na produção literária na qual se inserem os Diários Literários.

\section{A escrita kana e o desabrochar das novas formas literárias a partir do século $X$}

O Japão, sendo um país ágrafo, produziu seus primeiros registros escritos após o contato com a cultura continental chinesa, tomando-lhe de empréstimo a escrita, que já teria entrado muito antes do século V. Durante um longo processo de assimilação do chinês como língua estrangeira e do uso dos ideogramas, houve uma adaptação 
dos mesmos com a criação de regras de leitura para os textos chineses (kanbun) para grafar a língua japonesa de sistema sintático e fonético distinto. Inicialmente, os japoneses leram e redigiram em chinês, como mostram os documentos de teor burocrático, para então desenvolverem uma leitura adaptada à língua japonesa com o emprego dos chamados man 'yôgana e senmyōgaki, e os primeiros registros japoneses foram produzidos a partir da introdução dos conhecimentos adquiridos no continente chinês com a adaptação da escrita chinesa à realidade da língua japonesa. Contudo, apesar da implantação da cultura do continente asiático, a cultura popular tradicional transmitida desde os tempos antigos foi mantida, e o impulso cultural, responsável pelo novo desenvolvimento da cultura japonesa a partir do século VI, continuou com a mesma intensidade no século VIII.

A decadência da dinastia chinesa Tang e o encerramento das expedições culturais ao continente só contribuíram para que o Japão, que já apresentava uma forte tendência de manter e preservar a cultura nacional começasse a desenvolver uma literatura autóctone.

Apesar de facilitar a escrita da língua japonesa, o man'yōgana não mantinha uma uniformidade entre os seus usuários e limitava o seu emprego. Assim, baseado num sistema que atendia aos fonemas japoneses desenvolvido entre o final do século IX e início do século $\mathrm{X}$ a partir da simplificação dos ideogramas utilizados como man'yōgana, ou seja, dos ideogramas usados para representar os vocábulos a partir dos fonemas japoneses, a escrita hiragana propiciou uma expressão mais livre dos sentimentos e dos pensamentos na língua japonesa, o que em última instância, gerou o florescimento de uma literatura que poderíamos caracterizar de propriamente autóctone.

Assim, ao contrário do que era de se esperar, a poesia chinesa que predominara no cenário japonês como mostram as coletâneas de poemas chineses editadas por ordem imperial como o Bunka Shüreishū, Ryounshü (Imperador Saga 809-823) e Keikokushü (Imperador Jun na 823-833) não fizeram desaparecer o poema japonês, este apenas lhe cedera o lugar de destaque. Assim, ajudado pela escrita fonogramática, o poema japonês waka, começou a ganhar força e assumiu a posição dominante na literatura palaciana. Pode-se dizer, assim, que mesclas sino-japonesas estiveram presentes durante todo o período de importação dos elementos chineses, pois, naturalmente, a influência do pequeno número de pessoas que retornavam da China teria ficado restrita à elite japonesa e a propagação dos mesmos foi sofrendo adequações no contato com as diversas características japonesas. A literatura chinesa passou por um processo de adoção imitativa e de assimilação, ao final do qual surge uma literatura híbrida em que prevaleceram os elementos japoneses.

No Prefácio da referida Coletânea de Poemas Waka de Outrora e de Hoje com cerca de 1100 poemas produzidos pela classe nobiliárquica, dentre eles 450 de autores anônimos, Kino Tsurayuki, um de seus organizadores, salientou a predominância da forma poética waka em 31 sílabas entre os poemas coligidos e analisou obras dos seis 
poetas mais brilhantes do início do século $\mathrm{X}$. Diante da necessidade de adotarem-se critérios estéticos e estilísticos, teorias poéticas foram produzidas pelos elaboradores das coletâneas e das antologias e pelos juízes dos encontros poéticos conhecidos pelo nome de utaawase, um tipo de jogo literário que se torna parte importante da vida cultural da nobreza da época e nos quais os poetas disputam entre si a supremacia de suas composições submetidas à apreciação de um juiz.

Desde então, ao lado de muitas coletâneas particulares, foram compiladas por ordem imperial, 21 grandes coletâneas de poema waka conhecidas pelo nome de Nijüichidaish $\bar{u}$ que contaram com a participação de poetas e poetisas de notoriedade.

É possivel perceber que a nova escrita começou a ser utilizada inicialmente nos poemas, em seguida, nos diários literários e, por último, nas narrativas. Cumpre observar que o termo "narrativa", tradução dada ao termo japonês monogatari, é utilizado de modo amplo na literatura japonesa e serve para designar tanto as obras de cunho histórico como as de natureza literária. Taketori Monogatari (Narrativas do Cortador de Bambu), chamada de "obra ancestral das narrativas" surgiu entre 900 e 902 , e ainda foi escrita com os ideogramas chineses utilizados em sua leitura adaptada para o japonês, supostamente escrita por estudiosos e bonzos no século $\mathrm{X}$ que compilaram a literatura oral transmitida de geração para geração. A primeira obra posterior a ela foi Ise Monogatari (Narrativas de Ise, 946), que parece ter assumido o formato atual em meados do séc. X, mas teria sido escrito no final do séc. IX por alguma pessoa ligada a Ariwarano Narihira (825-880) ou por ele mesmo, cujos poemas e histórias assumem a parte central da narrativa.

Os japoneses começaram a ter o domínio da expressão escrita manifestando livremente seus sentimentos e pensamentos por meio da escrita hiragana, mas os homens demoraram a se desvencilhar dos textos estrangeiros escritos em chinês, de modo que a escrita hiragana se estabelece pelas mãos das mulheres instruídas da corte Heian, e é nesse aspecto que entra o espírito inovador de Kino Tsurayuki que inaugurou a literatura de diário utilizando a voz narrativa feminina no Diário de Tosa.

Shimauchi Keiji (1997) considera que o Diário (literário) e a Narrativa aproximam-se quanto ao conteúdo, como narrações de uma vida que merece ser destacada, e distanciam-se no ponto de vista, na medida em que a Narrativa apresenta um narrador que observa a existência feminina pelo ângulo de visão masculino e o Diário (literário), um narrador mergulhado na existência feminina. Este último, seria um relato direto de uma experiência singular, com um narrador autodiegético, um narrador protagonista ou personagem, e a primeira, o relato indireto de uma experiência igualmente singular com um narrador heterodiegético, que não é um protagonista da história que ele narra, fazendo com que a distinção entre o Diário (literário) e a Narrativa estaria basicamente no foco narrativo. Contudo, entendemos que tal divisão não dá conta de classificar os diários literários japoneses que são escritos tanto em primeira quanto em terceira pessoa. Em se tratando de diários, a expectativa é de que sejam autodiegéticos, mas isso não se aplica às duas obras aqui 
focalizadas que foram escritas na terceira pessoa do singular, algo inusitado para um novo gênero que se diz ser um diário e que leva a supor que a voz narrativa utilizada seja a primeira pessoa do singular, sugerida pela própria natureza intimista e privada dos diários.

\section{A voz narrativa no Diário de Tosa}

Em 930, Tsurayuki foi designado governador da Província de Tosa, atual Província de Kōchi, localizada na ilha de Shikoku ao sudoeste do arquipélago japonês, para um mandato de quatro anos que se estendeu por mais um ano, devido ao atraso da chegada de seu sucessor, e o Diário de Tosa narra a viagem de volta de Tsurayuki e sua comitiva para a Capital, na forma de um diário que tem início no dia 21 de dezembro de 934, data em que ele deixa o palácio do governo após a recepção do novo governador e a troca de posse, e termina com a chegada a sua residência em 16 de fevereiro de 935 , cinqüenta e cinco dias depois.

$O$ registro desses exatos cinqüenta e cinco dias, mesmo quando consta apenas a data com a informação de que nada acontecera de diferente ou relevante, imprime verossimilhança ao diário e, ao mesmo tempo, transmite a sensação de delonga $\mathrm{e}$ tédio que geram inquietação entre a comitiva, ansiosa por chegar ao seu destino. O Diário de Tosa é um registro posterior, mas é como se cada dia tivesse sido registrado durante a viagem. Várias passagens e acontecimentos trazem a recordação melancólica da filha de Kino Tsurayuki que com ele fora para a Província de Tosa e lá viera a falecer e mostram sua tristeza por não tê-la junto a si no regresso à Capital ao final do mandato. Desse modo, o louvor à memória da filha perdida durante o mandato em Tosa serve como tema central e fio condutor da obra e condiz com a natureza de memória que o diário literário possui.

Na narrativa, está presente a nostalgia que acompanha a viagem, sobretudo, na ansiedade por se chegar à capital, a crítica severa com ironias picantes aos interesseiros e levianos encontrados durante o trajeto e as muitas tradições culturais, sejam elas ligadas às datas festivas resgatadas pela lembrança, registradas por meio da composição de um poema e, por vezes, praticadas pela comitiva mesmo sem as condições necessárias às suas realizações ou ligadas ao culto às divindades frente ao temor do mau tempo e da ameaça de investidas por parte de piratas. É digno de nota o episódio em que o timoneiro sugere à comitiva que lancem oferendas ao mar quando enfrentam ventos fortes que impediam o barco de avançar. Nusa, um objeto religioso feito de papel, é arremessado n'água, mas isso só faz aumentar a fúria da divindade local, os ventos ficam mais intensos, e novamente o timoneiro intervém: "A divindade não ficou satisfeita com o nusa, por isso a viagem não avança. Ofereçam algo que a deixe mais feliz" É, então, oferecido um espelho após o seguinte comentário: "Não tem jeito. Até para a visão que é tão preciosa temos dois olhos, mas somos obrigados a oferecer o único espelho que temos" Após lançar n'água esse objeto de valor material como oferenda, o mar abranda e 
sua superfície fica lisa como a de um espelho e, o final deste incidente encerra-se com a observação da narradora sobre a ambição do timoneiro por trás do desejo da divindade por oferendas valiosas.

No prefácio da Coletânea de Poemas Waka de Outrora e de Hoje, Kino Tsurayuki focalizou a essência do poema e após enumerar os estilos dos mesmos, comenta os exemplos de composições feitas pelos seis poetas mais brilhantes da época, e o estudioso Hagitani Boku, por sua vez, apresenta, entre outros aspectos interessantes, que o Diário de Tosa é um tratado poético para os jovens iniciantes do waka. De fato, a importância da métrica em 31 sílabas do poema é ressaltada no episódio em que uma ordem dada ao barco pelo timoneiro, sem que este tivesse tido a intenção de compor um poema, soara como se o fosse por ter a mesma métrica do waka. Fatos semelhantes podem ser constatados em outras partes do texto pelo comentário da narradora sobre a qualidade de um poema composto por uma menina e que, apesar de não explicitar os motivos como no caso da métrica, serviria de exemplo não muito bem sucedido. Nesse mesmo sentido, há, ainda, passagens cômicas em que o chefe do barco vira alvo de fuxicos ao esmerar-se na composição de um poema que nem por isso fica bom.

Os 61 poemas waka constantes nessa obra podem, assim, ser considerados modelos para serem ou não seguidos, cada qual apresentando suas peculiaridades, as condições em que foram criados, ora motivados por um acontecimento, ora por uma paisagem de grande beleza.

A inserção desses poemas waka apresentados na obra como composições feitas em diversas situações ao longo da viagem pelos integrantes da comitiva do governador imprimem grande dose de subjetividade ao texto num misto de relatos de impressões e emoções demonstradas nas alegrias e nas angústias, nos encantos e decepções, temores, expectativas e esperança. No entanto, além da composição em versos de 5 , $7,5,7$ e 7 sílabas enquanto métrica que caracteriza um poema waka totalizando 31 sílabas, não há nenhuma orientação sobre a divisão formal do poemas em estrofes que estudos posteriores estabeleceram em duas chamadas de kaminoku (estrofe superior) $\mathrm{e}$ shimonoku (estrofe inferior), podendo o poema ser classificado como nikugire quando a primeira estrofe é formada pelos dois primeiros versos e de sankugire quando formada pelos três primeiros. Também não mereceram destaque outras pequenas regras como a quantidade excedente de sílabas permitida chamada de jiamari ou a falta conhecida pelo nome de jitarazu. A ênfase, desse modo, recai no conteúdo do poema, melhor dizendo, sobre as comparações ou símiles como a espuma da onda do mar com a neve ou flores brancas e das próprias ondas como os ramos do salgueiro verde. Nota-se que em todos os poemas utilizados como exemplo, há uma valorização da imagem visual da qual decorrem as inspirações poéticas que retratam a beleza da natureza e os devaneios das emoções humanas em ricas associações. Isso nos leva a observar que nesta obra, considerada um tratado de poesia, a motivação poética, freqüentemente explicitada, merece mais destaque que a questão formal e ilustra como o poema faz 
parte do cotidiano dos japoneses sendo apreciado e vivenciado tanto pelos adultos quanto pelas crianças, independentemente de seu sexo.

No mesmo sentido, podemos dizer que apesar de encontrarmos o recurso de homofonia conhecido como kakekotoba, a exemplo do termo omoshiroi (agradável), que por ter shiroi (branco) como parte de sua formação, remeteria à cor das ondas e das gaivotas, nenhum comentário é feito a esse respeito no sentido de ensiná-lo ou salientar a sua importância na composição poética.

A utilização da narrativa em terceira pessoa em voz feminina, contudo, possibilita observar que como um tratado poético, o Diário de Tosa apresenta dois lados de uma mesma moeda. Mesmo destinado a iniciantes, deixa a desejar na medida em que a narradora faz, como uma das integrantes da comitiva do governador, um exercício de imitar os diários oficiais sem a devida instrução como mostra a passagem em que ela declara "Não sou capaz de registrar aqui esses poemas chineses", que os governadores e seus funcionários compuseram e recitaram em alto e bom som na hora da partida. Tal fato, por sua vez, faz com que o poema japonês waka seja valorizado como uma forma poética ao alcance de todos, com uma métrica definida em 31 sílabas, sem grandes exigências de outros detalhes formais, e cuja ênfase recai sobre a motivação poética, pois imediatamente após mencionar as palavras acima citadas, vêm os dois primeiros poemas waka da obra, o primeiro composto pelo exgovernador, e o segundo, como resposta, pelo governador recém-empossado, depois dos quais vêm os demais e são eles que ficaram registrados para a posteridade apreciar e não os poemas chineses.

Desse modo, é inegável que o Diário de Tosa apresenta aspectos que nos permitiriam considerá-lo um tratado poético, mas certamente a sua faceta mais importante é a nova forma literária dessa obra resultante do brilhantismo de um artista como Kino Tsurayuki que empregou a voz narrativa feminina sob o pretexto de escrever na forma de escrita kana e com ela expressar o pensamento e a emoção, os sentimentos que antes eram difíceis de registrar por meio da língua estrangeira que era o chinês, seja em prosa ou em poesia.

O estudioso Itō Hiroshi (1989) menciona a existência de diários anteriores ao Diário de Tosa como o Taikó Gyoki (Diário da Imperatriz Onshi) escrito pela Imperatriz Onshi (885-954), esposa do Imperador Godaigo, e Enki Jüsan'nen Kyoshi In Utaawase (Reunião Poética de Kyoshi no Ano 13 de Enki, 913), com suposta autoria de Ise, mas salienta que os mesmos não passam de registros de eventos e que não apresentam qualidades literárias como as do Diário de Tosa que inaugura um novo universo na literatura japonesa.

Nesse sentido, o Diário de Tosa parodia um relatório de viagem de um oficial do governo ao término de seu mandato, mas apesar desse teor de realidade que transcreve os fatos aproveitando um episódio verídico, o Diário de Tosa apresenta características diferentes dos diários oficiais. Primeiramente, Tsurayuki escreve-o na recém-desenvolvida forma de escrita, ou seja, em fonogramas kana até então usado 
pelas mulheres, e emprega a voz narrativa feminina, como que justificando essa atitude e encenando a vontade de uma integrante da comitiva de imitar uma prática exclusiva dos homens em seus diários burocráticos denominados de niki, escritos em chinês. Ao mesmo tempo, imita os diários pessoais já existentes na época e escritos pelos homens em chinês ou chinês adaptado ao japonês. Tais fatos tornam-se interessantes, pois as obras que posteriormente seguem esse modelo e vão constituir parte da chamada Literatura de Diário são escritas principalmente pelas mulheres da aristocracia.

Pelo início da obra que diz:

Partimos em viagem por volta das oito horas da noite do vigésimo primeiro dia do décimo segundo mês de um determinado ano. Relato o ocorrido neste modesto registro,

o estudioso Nakano Koichi (1984) supõe que a intenção de Tsurayuki era a de escrever um diário de viagem desde a partida da província de Tosa, até a chegada à capital Quioto e que, pela frase inicial do Diário:

Eu, como mulher, escrevi um diário, o qual geralmente é escrito pelos homens.

ele teve em mente os diários de viagens escritos em chinês pelos governadores em suas idas e vindas das províncias para as quais eram nomeados, e, embora se trate de um registro posterior ao Diário de Tosa, dá como exemplo Tokinoriki (Registro de Tokinori), escrito por Tairano Tokinori nos dois meses de viagem de seu regresso à capital como ex-governador de Inaba. Na visão de Nakano, ao fazer com que o diário de viagem em chinês fosse escrito por uma mulher, o autor tornou possível o abandono do estilo característico de registro para conseguir meios de expressar mais livremente os sentimentos pessoais que não lhe seriam permitidos enquanto oficial do governo no cumprimento do dever.

Kino Tsurayuki inaugurou, desse modo, um novo gênero com o Diário de Tosa, uma obra híbrida em poema e prosa, semelhante a um diário poético e cuja voz narrativa feminina conduz inserções introdutórias e explicativas sobre os poemas criados em torno dos acontecimentos e emoções vividas pelas personagens.

Motivado ou não pela voz narrativa feminina que o poeta Tsurayuki empregou no Diário de Tosa, coincidentemente Kagerō Nikki (Diário do Pirilampo, \pm 974 ), a segunda obra do gênero da qual se tem conhecimento, foi escrita pela mãe de Fujiwarano Michitsuna, obra que iniciou a literatura de diário feminino desenvolvida nesse período em que as mulheres tiveram destaque na corte japonesa revelando seus dons artísticos na prosa e na poesia. Nesse mesmo período surgiram as famosas obras 
Makura no Sōshi (Livro de Cabeceira, 1001) de Sei Shonagon e Genji Monogatari (Narrativas de Genji, 1008) de Murasaki Shikibu.

Kagerō, nome desse primeiro diário feminino, possui duas acepções: "pirilampo" ou "efeito da sombra, do sombreamento", e foi atribuído pela própria autora que iniciou a obra com o desejo de escrever sobre os seus dias de espera pelas visitas do marido, Fujiwarano Kaneie. Concluído entre 974 e 978, quando ela estava na faixa dos quarenta anos de idade, o relato em primeira pessoa de suas experiências sobre a vida real era uma novidade atraente em meio às estórias antigas do reino da fantasia cheia de romantismo que predominavam em seu tempo. É claro que embora a intenção da autora tenha sido a de retratar a situação objetiva de sua vida, a realidade dos fatos é apreendida através de sentimentos individuais e subjetivos e essa obra constitui uma formalização de sua interioridade que aborda questões em torno da infelicidade feminina da sociedade aristocrática de sua época.

\section{O Diário de Izumi Shikibu}

Diferentemente do Diário do Pirilampo, o primeiro diário feminino, o Diário de Izumi Shikibu foi escrito na terceira pessoa do singular, como é o caso do Diário de Tosa, e por isso mesmo deixou questionamentos sobre sua autoria e seu gênero. Contudo, os pormenores da vida íntima de Izumi Shikibu e o enredo centralizado nos poemas de sua autoria focalizando apenas esse episódio da vida da autora fizeram com que ele permanecesse na classificação de Diário e não de Narrativa e predominasse a tendência de atribuir à poetisa a autoria.

É uma obra em prosa que se desenvolve centralizada em mais de 160 poemas, um número elevado se considerada a sua pequena extensão, e por isso também é considerado um diário poético. Apresenta o episódio da vida de uma dama que ao terminar o período de luto do marido alcança sucesso num novo romance atribulado com o cunhado.

O enredo tem início com o cortejo amoroso do Príncipe Atsumichi, por volta de abril de 1003, pouco depois de terminado o luto da protagonista pela morte do Príncipe Tametaka, esposo de Izumi Shikibu e irmão mais velho de Atsumichi, e narra a vida amorosa da viúva protagonista com o cunhado, até ser acolhida por ele, dez meses depois, no ano novo, vencendo todas as oposições e saindo triunfal perante a sua esposa oficial que deixa o palácio quando o Príncipe a leva para morar nele. A relação da dama com o Príncipe mostra o jogo amoroso que envolve o cortejo inteligente e requintado pela troca de poemas que exercem uma função de diálogo em forma de mensagens ou recados escritos.

O Japão dessa época era poligâmico para os homens e monogâmico para as mulheres e estas disputavam entre si um lugar no coração de seus amados. Nesse sistema, as regras da conquista amorosa fundamentavam-se basicamente no jogo de sedução pelas palavras com a troca de poemas. 
Utilizados pela classe aristocrática da época como cartas, inclusive para o cortejo amoroso, os poemas compostos pela dama e pelo Príncipe cumprem uma função de diálogo entre eles.

Ambientada num espaço restrito, que é a casa da dama, o palácio e o templo na cidade de Quioto e circunvizinhanças, a obra apresenta poucos personagens além dos protagonistas: o pajem, o acompanhante do Príncipe, a pajem, a ama-de-leite e a esposa do Príncipe. O tempo da narrativa é de dez meses, mas as marcações temporais são diluídas ao longo do texto, que perde a característica de um diário com datas demarcadas em destaque, como acontecem com o Diário de Tosa e o Diário do Pirilampo, seus precursores.

Em nenhum momento, a autora tem seu nome mencionado na obra. Também não constam informações diretas sobre a protagonista identificada poucas vezes como "a dama", e que permitam associar o episódio do diário à vida real de Izumi Shikibu. As pistas para se saber que a dama protagonista é Izumi Shikibu são apenas o título da obra, os dois Príncipes que tiveram um caso amoroso com ela e os poemas, muitos dos quais reunidos na Coletânea de Poemas de Izumi Shikibu que possui um número superior a 1500 poemas. São encontradas, ainda, menções de que o pajem mensageiro das cartas do Príncipe Atsumichi é o mesmo que havia servido ao falecido príncipe Tametaka, irmão mais velho de Atsumichi; quase ao final, uma fala da ama-de-leite que reclama sobre as visitas do príncipe à casa da dama lembra que o falecido irmão também saía com o mesmo acompanhante para ir aos encontros com a dama.

Disso decorrem os questionamentos já mencionados sobre a autoria dessa obra que por vezes foi atribuída a Fujiwarano Toshinari ou Shunzei, como era conhecido esse renomado poeta da corte. No entanto, os estudos tendem a apontar para a autoria da poetisa justamente em função de sua identificação com a protagonista chamada de onna (mulher), que traduzimos por "dama", pelas referências a três figuras masculinas que fizeram parte da vida dela. Tachibana no Michisada, Governador da Província de Izumi, com quem ela esteve casada entre 999 e 1004, donde provém o seu nome; Príncipe Tametaka, filho do Imperador Reizei com a Imperatriz Shōshi, a quem ela se uniu antes da separação com o primeiro marido e que faleceu em 1002 aos 26 anos e o Príncipe Atsumichi, irmão mais novo de Tametaka, com quem ela inicia a relação na primavera de 1003, e vem a falecer em 1007 quando ele contava 27 anos. Além disso, seus poemas de elegia a Atsumichi chegam a mais de 120 , o que mostra um envolvimento especial da autora com essa obra que narra o episódio que teria sido o mais romântico e cheio de emoções que foi o do cortejo amoroso até a sua acolhida triunfal no Palácio. $\mathrm{O}$ uso da terceira pessoa torna-se assim, um recurso literário para ostentar a glória da poetisa nessa conquista bem sucedida não apenas por meio de sua beleza física e encanto sedutor, motivo pelo qual era criticada, como também, e sobretudo, pelo seu talento artístico.

Ela evidencia, assim, o valor da mulher da época, e ainda mais no seu caso, a uma vitória pessoal enaltecida. A esposa oficial de Atsumichi retira-se do palácio 
com a chegada da nova mulher de seu marido. Ao contrário das lamentações das mulheres que enfatizam o esquecimento após o cortejo e a conquista, a glória é o foco da narração. Izumi Shikibu não registrou o seu episódio como o de uma mulher a mais na vida de Atsumichi como é o caso do diário da autora de Kagerō, que como diz o nome da obra, ficou na sombra, brilhou apenas um tempo do breve reluzir intermitente do pirilampo, assim como o de outras mulheres que passaram e viriam a passar na vida de Fujiwarano Kaneie. Por isso, a narrativa do Diário de Izumi Shikibu é encerrada no auge da glória e não nos informa sobre a vida após a união. A quem mais poderia interessar essa atitude de enaltecimento próprio além da própria Izumi Shikibu? Fujiwarano Shunzei teria sido um admirador seu, ou das mulheres de seu tempo, a ponto de escrever justamente sobre o grande amor dela e colocar os louros nela e em Atsumichi? É pouco provável que haja um autor tão interessado em registrar esse momento grandioso da vida de uma dama que foi corteja por muitos. Por isso, tendemos a aceitar a opinião de estudiosos como Hirata Hironobu que defendem a autoria de Izumi Shikibu.

Os poemas do Diário de Izumi Shikibu são do tipo zōtōka, poema dedicatório ou poema resposta, trocado entre um casal no cortejo amoroso. Segundo os estudos antropológicos, a origem dos zōtōka remonta ao relacionamento entre homens e mulheres no evento com origens no século VI conhecido como utagaki no qual homens e mulheres se divertiam dançando com músicas populares e dialogando sobre o amor. O estudioso Hasegawa Masaharu (1986), baseado na visão de que esses poemas trocados entre dois indivíduos específicos abrangem um conteúdo que vai desde declarações amorosas até as alegrias e tristezas do dia-a-dia e de que a relação entre esses indivíduos também é das mais variadas, aponta para a predominância de temas sobre o amor e que estes últimos tinham por objetivo a auto-promoção, superar o poema do proponente. $\mathrm{O}$ poema valia tanto quanto a própria vida do compositor e por isso, especialmente no caso das mulheres, surgiram poemas excepcionais. Era preciso seduzir e conquistar um bom partido por meio da inteligência e da criatividade manifestadas nos poemas.

Se a conquista amorosa se realizava pela troca de poemas, fazia-se necessário que as partes envolvidas demonstrassem grande erudição nas áreas do saber da época, nível de instrução elevado e, acima de tudo, inteligência e refinamento, conforme enfatiza o estudioso Sasaki Yukitsuna (1999).

O episódio amoroso da dama e do príncipe no Diário de Izumi Shikibu mostra esse jogo de sedução e conquista permeado de habilidosas técnicas de composição poética que atestam o elevado nível de instrução e conhecimento e o requinte literário dos envolvidos.

A maior parte dos poemas forma um tipo de diálogo entre a dama e o príncipe, tecem a obra mesclando trechos de narração. Verificando a cadeia de poemas que se seguem ao longo da obra, notamos que há um primeiro composto pela dama e dois sucessivos provenientes do príncipe, de modo que ocorra uma sequiência de poemas 
intercalados, compostos por um e por outro. Entre eles, o 93a e 93b são efetivamente um poema encadeado, conhecido pelo nome de renga. Considerando-se, porém, que os poemas constituem um diálogo de continuidade na comunicação entre o casal, teremos uma forte conexão entre o conjunto por meio de imagens e homofonias que remetem a outras circunstâncias e lembranças trazidas à tona por meio de recursos estilísticos próprios da poesia japonesa.

O diálogo tem início com a chegada do pajem do príncipe levando à dama, sua cunhada, um ramo de tachibana, um objeto real, uma flor com um perfume peculiar, que é imediatamente associado por ela ao poema de autoria desconhecida constante entre os poemas de verão do Rolo 3 do Coletânea de Poemas Waka de Outrora e de Hoje. Certamente, o príncipe Atsumichi teria feito esse gesto ciente de que ele seria entendido por tão instruída e perspicaz dama. E de fato, ao recebe a flor, a dama é levada naturalmente a murmurar "mukashi no hito no"「草の人の」 “da pessoa de outrora", aproveitamento de um original, um dos recursos estilísticos para aludir a um poema no texto da narrativa designado pela expressão japonesa hikiuta hyōgen.

É possível interpretar que esse verso de sete sílabas remeta à dama a lembrança de seu marido, irmão mais velho do príncipe Atsumichi que lhe oferecera a flor levada pelo pajem, mas também a de Tachibanano Michisada, primeiro marido de Izumi Shikibu e Governador da Província de Izumi do qual provém o nome pelo qual ela ficou conhecida.

Diante do pajem com a flor em mãos, a viúva, por um instante, hesita se deveria responder ao gesto de Atsumichi, mas depois, decide fazê-lo sem a menor intimidação e de imediato, convidando-o de modo sutil e requintado para um encontro, por meio de um poema que é levado de volta pelo mesmo pajem. Uma atitude destemida por parte da dama, que com essa atitude teria aceito o suposto cortejo de Atsumichi, ou tomado a iniciativa ousada de cortejá-lo. Nesse gesto impetuoso, observamos a capacidade de improvisação embasada em grande talento poético da dama, demonstrada ao longo dos poemas presentes na obra, e uma inteligência e astúcia que irá envolvendo cada vez mais o seu interlocutor até que ele a leve para a sua residência.

Os elementos imprescindíveis no jogo de sedução, como a demonstração da sabedoria e criatividade na composição de um poema, aparecem nesse Diário que se mostra como um registro de autoglorificação de uma dama que conquista o seu amor.

Mesmo assim, há nele um tom de tristeza e solidão por se tratar de um amor que não deveria acontecer, uma vez que vai sendo regado e cultivado com os poemas que encontram ressonância ao longo do tempo ao cantar os pássaros da primavera, as chuvas que antecedem o verão, as folhas avermelhadas e o luar do outono e a neve. A obra é marcada pela sucessão dos acontecimentos que trazem sinais das estações, com apenas algumas datas precisas. Muito mais que o registro de datas é o tempo da memória de momentos dignos de lembrança que vão desde a primeira manifestação de interesse do príncipe pela dama até a sua acolhida no palácio, mostrando a importância que ela tem em sua vida que ecoa a satisfação de ser a escolhida e valorizada. 
A questão da autoria da obra não chega a ser problema para o caráter literário da obra, pois em termos de resultado, se da autoria da própria Izumi Shikibu, evidencia a mesma técnica narrativa utilizada no Diário de Tosa e, ocultando a tristeza das mulheres daquela época por trás desse sucesso, enfatiza a vitória da dama conhecida como mulher fatal, sobretudo pelo fato de, diferentemente do Diário do Pirilampo, a narrativa encerrar-se no auge da conquista, com a cena de retirada da esposa oficial do Príncipe.

Dessa maneira, o Diário de Izumi Shikibu utiliza a mesma neutralidade do Diário de Tosa, por meio da terceira da pessoa do singular e com isso, a autora isentase de comprometer a imagem de Izumi Shikibu, ou seja, de si mesma, enquanto mulher sedutora e usurpadora do amor de Atsumichi, irmão mais novo de seu falecido esposo a quem devotou o seu amor ainda na companhia de Tachibana no Michisada, seu primeiro marido, pois, como mostra a sua coletânea de poemas, grande parte de suas composições é dedicada a esse grande amor de sua vida.

\section{Conclusão}

O Diário Literário nasceu em meio ao novo florescer dos poemas japoneses e da produção de obras em prosa, entre outros fatores, devido ao amadurecimento resultante do longo contato com o continente chinês e ao desenvolvimento de elementos adequados à expressão dos sentimentos e da natureza japonesa como a escrita kana, motivados pelo distanciamento da cultura chinesa.

Difundiu-se entre as mulheres da aristocracia, que se tornaram responsáveis por grande parte da produção literária desse período, em função do sistema político do clã Fujiwara que garantiu a manutenção do poder por meio de parentesco nãoconsangüíneo, aliado ao sistema poligâmico para os homens, vigente na época, dois sistemas que serviram de mola propulsora para essa produção expressiva da Literatura Feminina com obras literárias representativas desse momento histórico. $\mathrm{O}$ primeiro, no sentido de fazer com que as mulheres fossem criadas e instruídas com o máximo de zelo para servirem na corte e tornarem-se futuras esposas do Imperador, muitas vezes, possuindo privilégios até maiores que os dos homens dentro de uma família, e fazendo com que todo esse aparato gerasse outras atividades em torno delas, e o segundo, no sentido de fomentar as paixões da vida humana de alegria e tristeza, encanto e desilusão, rivalidade e instabilidade.

A obra Diário de Tosa inaugurou o gênero pela ousadia de Kino Tsurayuki, poeta da corte já em sua fase senil, ao utilizar a voz narrativa feminina e tentando fazer-se passar por uma autora-narradora que estaria parodiando os diários oficiais registrados tradicionalmente com o uso exclusivo de ideogramas escritos pelos homens, substituindo-o pela nova forma de escrita fonogramátia e fazendo um relato de viagem de regresso à capital da comitiva de um governador que deixava o seu posto, indo além do registro formal que lhe seria comum. 
Com a inserção de poemas e observações de grande sensibilidade, a obra assume um caráter laudatório à filha falecida em Tosa, e ao mesmo tempo, de uma espécie de tratado poético destinado aos iniciantes na arte do poema waka, mas acima de tudo, torna-se uma nova forma literária que propicia o seu desenvolvimento fora da elite masculina e que se consolida pelas mãos das damas da aristocracia e dá um passo a mais para o avanço da literatura, em termos de alcance na autoria ou no público leitor, podendo-se dizer que a voz narrativa feminina do Diário de Tosa abre espaço para o desenvolvimento dos diários literários femininos.

O Diário de Izumi Shikibu pertence à Literatura Clássica Feminina Japonesa, quando vigorava a poligamia masculina no mundo aristocrático, e os diários literários femininos iniciados com o Diário do Pirilampo constituem o primeiro passo para o desenvolvimento da Literatura Feminina que predominou entre o final do século $X$ e o início do século XII e com o registro de algumas nos séculos seguintes. Grande parte é escrita pelas nyōbo, mulheres dotadas de instrução que serviam na corte. No entanto, é discutível o quanto elas eram valorizadas social e familiarmente, pois, como podemos observar pelo quadro, nenhuma das autoras é conhecida a não ser pela sua ocupação ou pela relação familiar recebendo uma designação que tem por referência o filho, o pai ou o marido, e as obras literárias femininas desaparecem juntamente com a saída das damas da corte do cenário japonês.

A estrutura dos diários formada com a presença de grande número de poemas mostra que essa forma literária avança da poesia para a prosa, mas ainda permanece centrada nas formas poéticas tão presentes desde os primórdios e que serviram de processo mnemônico nos tempos em que não se desenvolvera a escrita.

No tocante ao hibridismo da obra que intercala a narrativa com poemas, assemelha-se às primeiras obras literárias japonesas de cunho histórico conhecidas como Kojiki (Registro de Fatos Antigos, 710) e Nihonshoki (Registros do Japão, 712) e cujo conjunto de poemas, num total de aproximadamente 190 composições poéticas se desconsideradas as que se repetem nas duas obras, é denominado Kikikayō, o conjunto de poemas das obras Registro de Fatos Antigos e Registros do Japão.

Observa-se, portanto, que após a invenção de uma escrita que permitiu expressar melhor os sentimentos dos japoneses, os poemas são os que mais se desenvolveram, e os diários surgiram em torno a ele ou a partir dele assumindo uma forma híbrida de poema e prosa. Uma narrativa que contextualiza os poemas com informações ou explicações, forma essa da qual se aproxima o Diário de Tosa, ou uma narrativa em que os poemas, ainda em grande quantidade, são inseridos como parte do contexto, acompanham o enredo, servindo como elementos descritivos importantes, mas do qual o enredo não é dependente, e o Diário de Izumi Shikibu, obra na qual os poemas não deixam de ser composição artística que exprimem emoções, mas funcionam como diálogo entre os protagonistas que fazem o enredo avançar como parte da trama. 
Um aspecto que mostra o desenvolvimento da prosa a partir dos poemas é o ponto em comum dos diários aqui focalizados, ou seja, o aproveitamento dos recursos estilísticos da poesia na parte narrativa do texto, no caso, kakekotoba, recurso de homofonia, e hikiuta hyōgen que é a mesma aplicação do honkadori, usado exclusivamente nos poemas.

Assim, a literatura japonesa, em sua fase de desenvolvimento de uma cultura autóctone, recupera e amplia o espaço perdido pelo poema japonês waka e diversificase a partir dele tendo no diário literário um processo de desenvolvimento da prosa que vai ganhando terreno com as outras novas formas literárias conhecidas como ensaios literários (zuihitsu), diários de viagens (tabi nikki) e narrativas (monogatari).

\section{Referências bibliográficas}

KUBOTA, Jun \& KAWAMURA, Teruo (org.). Hachidaishū (Coleção das Oito Grandes Antologias de Poemas Editadas por Ordem Imperial), Tóquio, Miyai, 1996.

HASEGAWA, Masaharu. "Nihongakutoshiteno retorikku: chūko nihongo - Waka to tsukurimonogatarino retorikku ("Estilística dos Estudos Japoneses: Língua Japonesa do Período Antigo - Estilística do poema waka e das narrativas de ficção") [Otono kankiryoku - kakekotobano baai. ("O poder de atração do som - o caso do kakekotoba")]. In: Kokubungaku Kaishaku to Kyōzai no Kenkyū. (Revista Literatura Nacional Interpretações e Pesquisas de Materiais Didáticos) Tóquio, Gakutōsha, Janeiro de 1986.

ITO, Hiroshi. Nikki Bungaku no Kaika, in:SUZUKI, Kazuo. Nihon Bungaku Shinshi Kodai II (Nova História da Literatura Japonesa Era Antiga II), Tóquio, Shibundō, 1989, p.115-149.

IZUMI SHIKIBU (provável autora) Izumi Shikibu Nikki (Diário de Izumi Shikibu), $9^{\mathrm{a}}$ ed. Ei'in Kōchū Koten Sōsho 22.Tóquio, Shintensha, 1994.

IZUMI SHIKIBU, Izumi Shikibu Shū / Zokushū (Coletânea de Poemas de Izumi Shikibu I, II), $9^{\mathrm{a}}$ edição, Tóquio, Iwanami, 1996.

KINO Tsurayuki. Tosa Nikki (Diário de Tosa), in: Shin Nihon Koten Bungaku Taikei 24, Tóquio, Iwanami, 1994.

NAKANO, Koichi, FUJIOKA Tadami \& INUKAI Kiyoshi. Kan'yaku Nihon no Koten Dai 24 kan Izumi Shikibu Nikki, Murasaki Shikibu Nikki, Sarashina Nikki.Tóquio, Shogakukan 1984.

SASAKI, Yukitsuna. "Koten Kidai no Kajin no Jōken" ("Os Requisitos de um Poeta na Época Clássica", in: Kokubungaku Kaishaku to Kyōzai no Kenkyū, (Revista Literatura Nacional - Interpretações e Pesquisas de Materiais Didáticos), Edição Especial: Poema, palavras poéticas e utamakura, novembro de 1999, p. 52-5. 
